\title{
Development of Raising Seedling Technology for Veronica pyrethrina Nakai Using Plug Trays
}

\author{
Hyuck-Hwan Kwon ${ }^{1}$, Hye-Jin Oh${ }^{1}$, Jin-Ho Kim ${ }^{1}$, and Sang-Yong Kim² ${ }^{2 *}$ \\ ${ }^{1}$ Assistant researcher, Division of Plant Resources, Korea National Arboretum, Yangpyeong 12519, Korea \\ ${ }^{2}$ Senior researcher, Division of Plant Resources, Korea National Arboretum, Yangpyeong 12519, Korea
}

\section{ABSTRACT}

Background and objective: This study was carried out to develop an effective technique for raising seedlings of Veronica pyrethrina Nakai, a native plant species in the Korean Peninsula, in plug trays.

Methods: To investigate the optimum plug cell size and sowing media, we sowed seed in to plug trays with 34,21 , and 10 $\mathrm{mL}$ cells and filled with a commercial horticultural substrate and mixtures of peatmoss and perlite in 1:1, 3:1, and 4:1 ratios. Fertilization levels were set at $0,500,1000$ and $2000 \mathrm{mg} \cdot \mathrm{L}^{-1}$.

Results: Plug cell size did not significantly influence the seedling growth of $V$. pyrethrina. By substrate type, the growth rate was highest in the horticultural substrate, followed by 4:1, 3:1, and 1:1. Growth by fertilization level was higher in all fertilized treatment groups than in the control group, and there was no difference among 500, 1000, and $2000 \mathrm{mg} \cdot \mathrm{L}^{-1}$. Conclusion: The results of this study proved that it is most suitable for raising seedlings of $V$. pyrethrina to sow the seeds in a $10 \mathrm{~mL}$ cell plug tray filled with horticultural substrates, and apply fertilizers with less than $500 \mathrm{mg} \cdot \mathrm{L}^{-1}$ concentration.

Keywords: breeding, growth characteristic, native plant, sub-irrigation, various substrate

\section{Introduction}

There are 4,177 species of native plants distributed in the fields and mountains of Korea (KPNI, 2021a), but since they grow without artificial protection in natural habitats (Song et al., 2015), they receive much less interest compared to exotic species. Plants used for cut flowers, potted flowers, garden flowers, and landscaping in Korea are mostly imported from other countries and have been established in real life for a long time, and thus people can easily buy them and access all kinds of information about cultivation and management. However, there is insufficient data on cultivation, propagation, and management of native plants. Native plants can express Korean-style emotions and have been adapting to the native land environment for a long time, thereby having strong environmental adaptability in different seasons as well as disease tolerance (Ryu, 2004), which is why more studies must be conducted on native plants.

Approximately 500 species of Veronica L. plants that belong to the family Scrophulariaceae are distributed in various habitats around the world (Albach et al., 2005). There are 23 species of Veronica growing naturally in Korea (KPNI, 2021b). $V$. pyrethrina Nakai is distributed at the foot of the mountains of Gyeongbuk, and its leaves are pinnate leaves that are egg-shaped or oval with round lobes, are $3-5 \mathrm{~cm}$ long and $1-2 \mathrm{~cm}$ wide with soft fur growing on both sides. Light purple flowers racemosely bloom about $8-10 \mathrm{~cm}$ in August (KPNI, 2021c), and they have high ornamental value as a Korean endemic plant and are worth using in gardens or landscaping in summer or fall. Previous studies on $V$. pyrethrina

This study is supported by the Korea National Arboretum's project "Discovery of Plants and Development of New Varieties for Industrialization of Wild Flowers (Project No.: KNA1-2-32, 17-7)".

Received: August 11, 2021, Revised: September 14, 2021, Accepted: September 29, 2021

First author: Hyuck-Hwan Kwon, kwon9270@korea.kr, (10) https://orcid.org/0000-0002-7071-010X

*Corresponding author: Sang-Yong Kim, rosaksy@korea.kr, (D) https://orcid.org/0000-0002-1819-5913 
Nakai determined the dormancy type of seeds (Song et al., 2019) or shade tolerance among environmental resistance (Kwon et al., 2020; Song et al., 2020), but none are on cultivation of seedlings. However, studies are recently conducted on ornamental Veronica, and Lee et al. (2020a) conducted a study on raising seedlings of mountain spike speedwell, discovering that it showed highest growth in horticultural substrates and excellent growth in Hyponex powder 1000 $\mathrm{mg} \cdot \mathrm{L}^{-1}$. Studies are also conducted to determine optimal growth of mountain spike speedwell (Lee et al., 2020b), and more research is necessary on ornamental Veronica.

Plug seedling production accelerates crop growth and adjusts production period, while also systemizing the process of raising seedlings such as watering, fertilization, and environmental management for labor saving, efficiency, stabilization, and year-round production. This enables year-round planned production of seedlings with even and standardized quality in seedling production facilities (RDA, 2021). Korea has been raising seedlings using plug trays for the plug seedling production system since the 1990s, Plug trays are enabling mass propagation while also specializing plant production by equalizing seedlings and reducing labor, thereby expanding the industry (Ito, 1992).

Many studies have been conducted using plug trays, which are known to affect crop growth depending on the number and size of cells. Bigger cells tend to lead to faster growth, longer period of seedling growth, better growth after planting, and bigger quantity (Shin et al., 2000; Kim et al., 2001; Kim et al., 2013). Moreover, Lee et al. (2005) examined seed germination rate of Miscanthus sacchariflorus Benth with different cell sizes of the tray, and the germination rate was highest in the 200-cell tray, and after that, growth in mixed substrates of peat moss and perlite was excellent regardless of cell size.

Furthermore, growth varied depending on the level of fertilization when raising seedlings of Thalictrum rochebrunianum var. grandisepalum (H. Lev.) Nakai and Thalictrum uchiyamae Nakai (Lee et al., 2015). Since plant growth varies depending on the treatment conditions when raising seedlings in plug trays, research must be conducted on suitable cultivation methods for each plant species. Therefore, this study was conducted to determine the cell size of plug trays, substrate types, and fertilization conditions when raising seedlings of $V$. pyrethrina Nakai, which is a native plant species.

\section{Research Methods}

\section{Testing materials}

$V$. pyrethrina Nakai seeds used in the experiment are those gathered and carefully selected from the greenhouse $\left(37^{\circ} 28^{\prime} 45.2^{\prime} \mathrm{N}, 127^{\circ} 35^{\prime} 51.4^{\prime \prime} \mathrm{E}\right)$ in Useful Plant Resources Center located in Yongmun-myeon, Yangpyeong-gun, Gyeonggido in November 2018, which were dried and stored for 27 months at $4^{\circ} \mathrm{C}$.

\section{Seedling growth depending on cell size of plug trays}

To identify growth of $V$. pyrethrina Nakai depending on cell size of plug trays, we used 72-cell, 128-cell, and 200-cell plug trays (Bumnong Co., Ltd, Korea) and the size of plug trays was the same regardless of cell size $(\mathrm{W} \times \mathrm{L} \times \mathrm{H}$ : $280 \times 540 \times 45 \mathrm{~mm})$. The cell size used was 72-cell (34 $\mathrm{mL} /$ cell $), 128$-cell $(21 \mathrm{~mL} /$ cell $)$, and 200 -cell $(10 \mathrm{~mL} /$ cell $)$. We filled each cell with horticultural substrates (Baroker, SeoulBio, Korea) and sowed 2-3 seeds in each cell. We applied bottom watering 1-2 times a week so that the medium does not go dry. We rogued the seeds a week after sowing so that the plants grow evenly in the trays. The experiment was conducted for 6 weeks in a phyto-garden where the temperature of $25 \pm 1{ }^{\circ} \mathrm{C}$, relative humidity of $70 \pm 5 \%$, photosynthetic photon flux density of $100 \pm 10 \mu \mathrm{mol} \cdot \mathrm{m}^{-2} \cdot \mathrm{s}^{-1}$, and day length of $9 / 15 \mathrm{~h}$ (day/night) can be controlled. We used LED for light source, and the wavelength was $406-770 \mathrm{~nm}$, and we used $458 \mathrm{~nm}$ white light for maximum wavelength.

\section{Seedling growth depending on substrate type}

For the experiment to identify the growth difference depending on substrate type, we used different types of substrates in the plug tray with $10 \mathrm{~mL}$ cells. We mixed horticultural substrate, peat moss (Profi2, Durpeta, Lithuania), and perlite (Supergreenpamix, Misung, Yesan, Korea) in the volume ratio of $1: 1,3: 1$, and $4: 1(\mathrm{v}: \mathrm{v})$ for the substrates, and sowed 2-3 seeds in each cell. The experiment was conducted for 6 weeks in a phyto-garden where the temperature 
and humidity are maintained. Before the experiment, we measured $\mathrm{pH}, \mathrm{EC}$, and water holding capacity of each substrate. We used the effluent obtained from diluting air-dried substrate and distilled water in the ratio of 1:5(v:v) and mixing them for 1 hour, and measured $\mathrm{pH}$ and EC using the PHmeter (Seven EasypH meter, Mettler Toledo, Switzerland) and EC-meter (EC Testr 11+, Eutech Instruments, Singapore). For measurement of water holding capacity of the substrate, we filled the pot with 15-20g of air-dried substrates and applied bottom watering for 12 hours, after which we discharged water for 30 minutes and measured the weight. The formula is as follows.

- Water holding capacity $(\%)=(\mathrm{WW}-\mathrm{DW}) / \mathrm{WW} \cdot 100$

(WW: wet weight, DW: dry weight)

\section{Seedling growth depending on fertilization level}

We filled the plug tray with $10 \mathrm{~mL}$ cells with horticultural substrates to determine the effect of fertilizer concentration on growth when raising seedlings, and sowed 2-3 seeds each. We used Peters (Peters professional, ICL Specialty Fetilizers, USA) for the fertilizer, composed of nitrogen $20 \%$, phosphoric acid 20\%, potassium 20\%, magnesium $0.05 \%$, boron $0.0125 \%$, iron $0.05 \%$, manganese $0.025 \%$, copper $0.0125 \%$, zinc $0.025 \%$, and molybdenum $0.005 \%$. The concentration of each treatment was 500, 1000, 2000 $\mathrm{mg} \cdot \mathrm{L}^{-1}$, and EC of each was $0.484,0.886,1.604 \mathrm{dS} \cdot \mathrm{m}^{-1}$. The untreated plot was the control plot, and fertilization was done by bottom watering for an hour once a week so that the substrates can sufficiently absorb the diluted fertilizer. The experiment was conducted for 5 weeks from April 16 to May 21, 2021.

\section{Survey items and statistical analysis}

We measured plant length, plant width, leaf length, leaf width, number of leaves, root length, shoot and root fresh weight and dry weight, and maximum quantum yield of $V$. pyrethrina Nakai. We measured plant length from the soil surface to the highest part of the plant body, and plant width with the thickest part of the plant body. We measured leaf length and leaf width with the biggest leaf out of completely bloomed ones. We measured the number of all leaves except those not fully bloomed and seed leaves. The growth survey was conducted with a completely randomized design repeating 3 times with 20 entities per treatment. We measured shoot and root fresh weight using an electronic scale (Shimadzu Analytical Balance AUW2200, Shimadzu, Japan) right after measurement, and we measured dry weight after measuring fresh weight and drying in a $70^{\circ} \mathrm{C}$ constant temperature drying oven for 72 hours. For chlorophyll fluorescence analysis, we selected 6 leaves per treatment, applied dark adaptation for 30 minutes, and used a chlorophyll fluorometer (Maxi Imaging-PAM-series, Heinz Walz GmbH, Effeltrich, Germany) to measure maximum quantum yield (Fv/Fm).

For statistical analysis, we conducted an analysis of variance using SPSS (SPSS 23.0, IBM Corporaton, USA), and conducted a post-hoc test at a 5\% significance level using Duncan's Multiple Range Test when the statistical difference is significant. The graph was developed using Sigma plot 10.0 (SPSS Inc., IL, USA).

\section{Results and Discussion}

\section{Seedling growth depending on cell size of plug trays}

As a result of the experiment on cell size of plug trays, plant length after 6 weeks was highest at $2.2 \mathrm{~cm}$ in $34 \mathrm{~mL}$, but plant width was $5.8 \mathrm{~cm}$, leaf length $2.1 \mathrm{~cm}$, leaf width $1.8 \mathrm{~cm}$, number of leaves 9 , root length $10.0 \mathrm{~cm}$, and shoot and root fresh weight and dry weight $234,37,24$, and 5 $\mathrm{mg}$, which were all higher in $10 \mathrm{~mL}$. However, there was no statistically significant difference by cell size (Table 1), and there was also no significant difference in maximum quantum yield (Fig. 1A). Previous studies on number of cells and size of individual plug trays proved that there was greater growth in bigger cells (Shin et al., 2000; Kim et al., 2001; Nam et al., 2003), whereas smaller cells of trays lead to smaller volume, which reduces nourishment and thus not enough for long-term growth. However, the root zone of the plant body grows and there can be root pruning. $V$. pyrethrina Nakai showed the most root development in $10 \mathrm{~mL}$, the smallest cells, but there was no significance in shoot growth depending on cell size. This indicates that 6 weeks are when the root zone develops, and at least 6 weeks are required in raising 
seedlings to show shoot growth. However, Kim et al. (2019) reported that smaller cell size leads to quicker root pruning after sowing, thereby moving up the time for planting, which as a result was effective in growth after planting. Hwang et al. (2018) reported that silver grass for landscaping did not show good growth with smaller cells when raising seedlings in plug trays, but seedlings raised in small cells showed excellent growth about 3 months after planting. The results of this study showed that $V$. pyrethrina Nakai did not show a difference in shoot growth when raising seedlings in plug trays for 6 weeks, but there was sufficient root pruning, and it seems effective to use $10 \mathrm{~mL}$ with small yet many cells to increase the yield after planting.

\section{Seedling growth depending on substrate type}

We measured $\mathrm{pH}$ and $\mathrm{EC}$ depending on the type of substrates used in the experiment. The horticultural substrate showed the lowest $\mathrm{pH}$ at 5.1 and highest EC at 0.96, and water holding capacity was high at $81.8 \%$ (Table 2). On the other hand, perlite showed the highest $\mathrm{pH}$ at 6.9 and lowest EC at 0.01 , and water holding capacity was $64.7 \%$. In general, perlite with thick particles shows about $20 \%$ of water holding capacity, but the type of perlite used in this experiment had small particles, which is why water holding capacity was higher. Peat moss showed higher EC than provided by the manufacturer, which is due to the different substrate storage conditions or measurement method. In the mixed substrate of peat moss and perlite $(1: 1,3 ; 1,4: 1)$, higher ratio of peat moss led to increased $\mathrm{pH}, \mathrm{EC}$, and water holding capacity. The results of the experiment showed that using the horticultural substrate led to excellent shoot growth, with plant length $1.7 \mathrm{~cm}$, plant
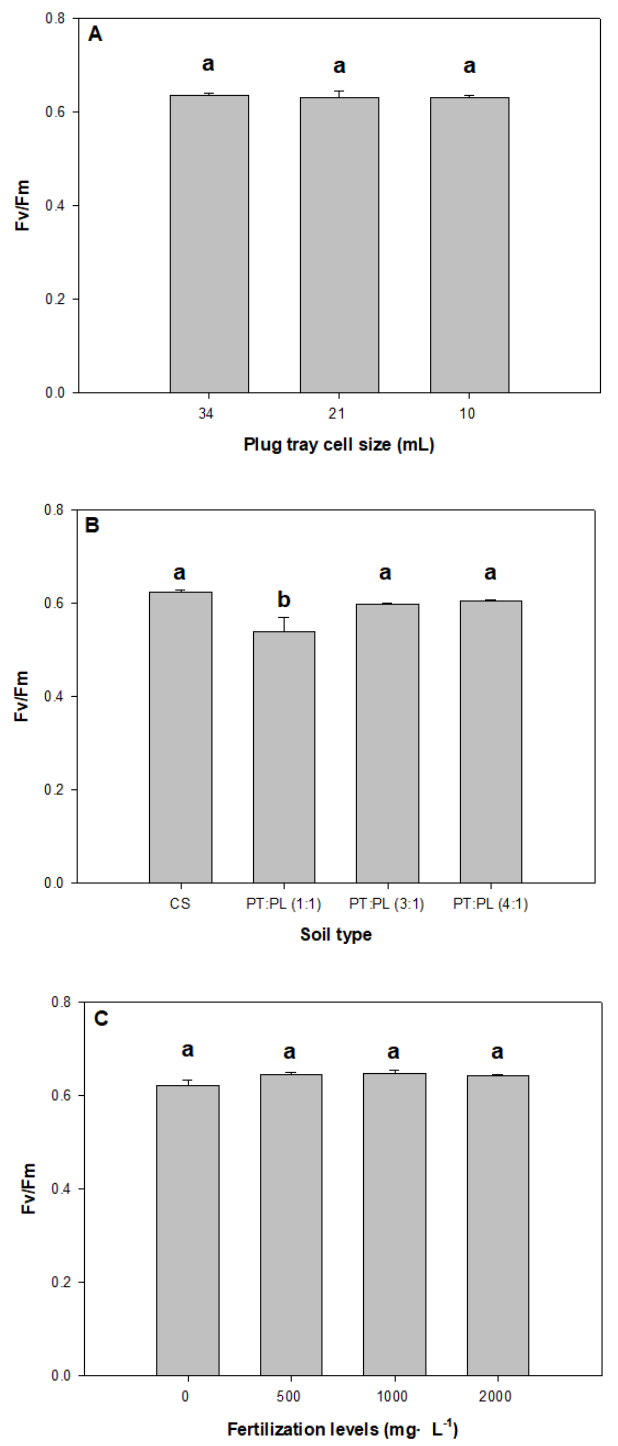

Fig. 1. The maximum quantum yield of Veronica pyrethrina under different plug tray cell size (A), substrate type (B), and fertilization levels (C). CS, horticultural substrate; PT, peatmoss; $\mathrm{PL}$, perlite. Means were separated by Duncan's multiple range test $(p \leq .05)$. Vertical bars represent SE $(n=3)$.

Table 1. Effect of plug tray cell size on growth characteristics of Veronica pyrethrina at 6 weeks after treatment

\begin{tabular}{|c|c|c|c|c|c|c|c|c|c|c|}
\hline \multirow{2}{*}{$\begin{array}{c}\text { Cell size of } \\
\text { plug tray }(\mathrm{mL})\end{array}$} & \multicolumn{2}{|c|}{ Plant } & \multicolumn{2}{|c|}{ Leaves } & \multirow[b]{2}{*}{ No. of leaves } & \multirow{2}{*}{$\begin{array}{l}\text { Longest root } \\
\text { length }(\mathrm{cm})\end{array}$} & \multicolumn{2}{|c|}{ Fresh weight (mg) } & \multicolumn{2}{|c|}{ Dry weight (mg) } \\
\hline & $\begin{array}{l}\text { height } \\
(\mathrm{cm})\end{array}$ & width $(\mathrm{cm})$ & $\begin{array}{l}\text { length } \\
(\mathrm{cm})\end{array}$ & width $(\mathrm{cm})$ & & & Shoot & Root & Shoot & Root \\
\hline 34 & $2.2 \pm 0.22$ & $5.5 \pm 0.32$ & $2.0 \pm 0.14$ & $1.7 \pm 0.12$ & $9.1 \pm 0.13 \mathrm{a}^{\mathrm{z}}$ & $9.1 \pm 0.18 \quad \mathrm{a}$ & $192.5 \pm 15.57$ & $22.6 \pm 0.16$ & $20.5 \pm 1.84$ & $3.4 \pm 0.51 \quad \mathrm{ab}$ \\
\hline 21 & $1.8 \pm 0.04$ & $4.8 \pm 0.04$ & $1.7 \pm 0.02$ & $1.5 \pm 0.01$ & $8.1 \pm 0.1 \quad b$ & $7.1 \pm 0.16 \quad b$ & $149.7 \pm 15.99$ & $19.2 \pm 3.32$ & $14.4 \pm 0.55$ & $2.7 \pm 0.13 \quad b$ \\
\hline 10 & $2.1 \pm 0.16$ & $5.8 \pm 0.5$ & $2.1 \pm 0.17$ & $1.8 \pm 0.14$ & $9.1 \pm 0.1 \quad a$ & $9.5 \pm 0.35 \quad \mathrm{a}$ & $234.3 \pm 32.43$ & $37.4 \pm 8.65$ & $23.7 \pm 4.18$ & $4.5 \pm 0.39 \quad \mathrm{a}$ \\
\hline Significance & NS & NS & NS & NS & $* *$ & $* *$ & NS & NS & NS & $*$ \\
\hline
\end{tabular}

${ }^{\mathrm{z}}$ Mean separation within columns by Duncan's multiple range test at $p \leq .05$.

${ }^{\mathrm{y}} \mathrm{Mean} \pm \mathrm{SD}$

$\mathrm{NS},{ }^{* *},{ }^{* * *}$ Non-significant and significant at $p \leq .01$ or .001 . respectively. 
width $4.4 \mathrm{~cm}$, leaf length $1.7 \mathrm{~cm}$, leaf width $1.5 \mathrm{~cm}$, and high fresh weight and dry weight (Table 3, Fig. 2). For shoot growth depending on the ratio of peat moss and perlite, the 1:1 mixed substrate showed lowest growth with plant length $1.4 \mathrm{~cm}$, plant width $3.4 \mathrm{~cm}$, leaf length 1.3 $\mathrm{cm}$, leaf width $1.1 \mathrm{~cm}$, and fresh weight and dry weight, while there was no significant difference in overall shoot growth in 3:1 and 4:1 mixed substrate. However, root length, fresh weight, and dry weight were lowest in the horticultural substrate. Lee et al. (1998) reported that, in the growth of Codonopsis lanceolata according to soil $\mathrm{pH}$, higher $\mathrm{pH}$ led to increased root weight. $\mathrm{Ku}$ et al. (2019) claimed that there is a difference in growth of cultivated chives and wild chives depending on soil $\mathrm{pH}$ concentration. $V$. pyrethrina Nakai showed lower root growth when the $\mathrm{pH}$ concentration was low. Moreover, maximum quantum yield was lowest in the 1:1 mixed substrate, while there was no difference in the horticultural substrate and mixed substrate $(3: 1,4: 1)$ (Fig. 1B), which is because water holding capacity decreased when the ratio of perlite increased in the mixed substrate of peat moss and perlite, which relatively caused water stress. Peat moss has many micropores inside and thus has high water retentivity (Choi et al., 2000), but plant growth becomes poor due to difficult gas diffusion with the formation of perched water tables when raising seedlings in plug trays (Nelson, 1991). To make up for this deficiency, the porosity and size inside the substance are generally increased by mixing perlite. Lee et al. (2020b) claimed that mountain spike speedwell did not show favorable growth in the mixed substrate of peat moss and perlite, but Yoo and Roh (2012) argued that roots of chrysanthemum 'Baekma' were long in the mixed substrate of peat moss and perlite $(2: 2,3: 1)$. Lee et al. (2005) also reported that raising seedlings of Miscanthus sacchariflorus Benth in the mixed substrate of peat moss and perlite (1:1) resulted in favorable growth of the root zone. $V$. pyrethrina Nakai also showed higher length, fresh weight, and dry weight of the root zone in the mixed substrate of peat moss and perlite. However, all parts of the shoot measured in the horticultural substrate showed excellent growth, and there was a significant difference with the mixed substrate, which was consistent with the result by Lee et al. (2020b) that using horticultural substrates is most effective when raising seedlings of mountain spike speedwell in plug trays. Moreover, horticultural substrates include nitrate nitrogen $\left(\mathrm{NO}_{3}-\mathrm{N}\right)$, available phosphate $\left(\mathrm{P}_{2} \mathrm{O}_{5}\right)$, ammonium nitrogen

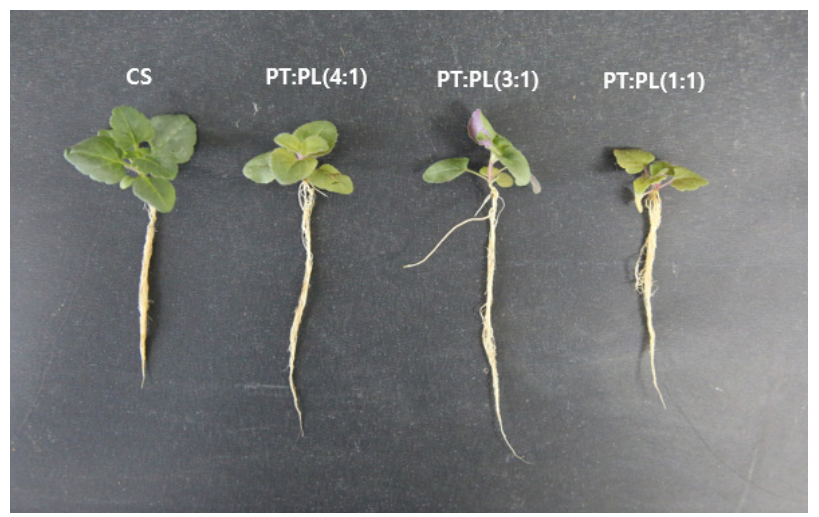

Fig. 2. Seedlings of Veronica pyrethrina Nakai grown for 6 weeks in different substrate type. CS, horticultural substrate; PT, peatmoss; PL, perlite.

Table 2. The properties of substrate in this study

\begin{tabular}{|c|c|c|c|c|}
\hline Substrate & $\begin{array}{c}\text { PT:PL } \\
\text { ratio }\end{array}$ & $\begin{array}{c}\mathrm{pH} \\
(1: 5)\end{array}$ & $\begin{array}{c}\mathrm{EC} \\
(\mathrm{dm} / \mathrm{s})\end{array}$ & $\begin{array}{l}\text { Water holding } \\
\text { capacity }(\%)\end{array}$ \\
\hline $\mathrm{CS}^{\mathrm{y}}$ & & $5.1 \pm 0.04 \mathrm{~d}^{\mathrm{Z}}$ & $0.96 \pm 0.053 \quad \mathrm{a}$ & $81.8 \pm 0.7 \mathrm{ab}$ \\
\hline PT & & $6.1 \pm 0.07 \mathrm{c}$ & $0.28 \pm 0.01 \quad b$ & $83.6 \pm 0.8$ a \\
\hline PL & & $6.9 \pm 0.16 \quad \mathrm{a}$ & $0.01 \pm 0.001 \quad \mathrm{~d}$ & $64.7 \pm 0.3 \mathrm{e}$ \\
\hline PT:PL & $1: 1$ & $6.2 \pm 0.04 \mathrm{bc}$ & $0.13 \pm 0.006 \mathrm{c}$ & $76.6 \pm 0.6 \mathrm{~d}$ \\
\hline PT:PL & $3: 1$ & $6.3 \pm 0.03 \mathrm{bc}$ & $0.23 \pm 0.002 \quad b$ & $78.7 \pm 0.7 \quad \mathrm{c}$ \\
\hline PT:PL & $4: 1$ & $6.3 \pm 0.01 \quad b$ & $0.25 \pm 0.01 \quad b$ & $80.3 \pm 0.7 \quad b c$ \\
\hline Significance & $* * *$ & $* * *$ & $* * *$ & $* * *$ \\
\hline
\end{tabular}

${ }^{\mathrm{z}}$ Mean separation within columns by Duncan's multiple range test at $p \leq .05$.

$* * *: p \leq .001$.

${ }^{\mathrm{y}} \mathrm{CS}$, commercial substrate; PT, peatmoss; PL, perlite.

${ }^{\mathrm{x}} \mathrm{Mean} \pm \mathrm{SD}$. 
$\left(\mathrm{NH}_{4}-\mathrm{N}\right)$, and microelements $(\mathrm{K}, \mathrm{Ca}, \mathrm{Mg}, \mathrm{Fe}, \mathrm{Cu}$, etc.), along with other types of substrates mixed in such as coco peat and vermiculite aside from perlite and peat moss included in the horticultural substrates. Therefore, it is efficient to use horticultural substrates when raising seedlings of $V$. pyrethrina Nakai in a tray, and manufacturing components must be considered in soil experiments since soils or microelements included vary depending on the manufacturer of horticultural substrates.

\section{Seedling growth depending on fertilization level}

Fertilization affects soil organic content, characteristics of microbes, and enzyme activity, thereby changing plant growth (Thirukkumaran and Parkinson, 2002; Compton et al., 2004; Frey et al., 2004), and the difference in plant species and nutrients in cultivating containerized seedlings results in deteriorated quality of seedlings (Juntunen et al., 2003; Hernández et al., 2009). The water-soluble fertilizer used in this study is $20-20-20+$ TE with a balanced content of macroelements and microelements, and it promotes delivery of nutrients and absorption into the plant body (ICL, 2021). As a result of the experiment, $V$. pyrethrina Nakai seedlings showed improved growth overall in fertilizer application than the untreated control plot (Table 4). Plant length showed a $0.6 \mathrm{~cm}$ difference with $2.1 \mathrm{~cm}$ in $500,2000 \mathrm{mg} \cdot \mathrm{L}^{-1}$ and $1.5 \mathrm{~cm}$ in the untreated plot, and plant width showed more than a $1.0 \mathrm{~cm}$ difference in all fertilizer application plots than the untreated plot with $5.2 \mathrm{~cm}$. Moreover, there was a significant difference from the untreated plot in leaf length and leaf width as well. There was almost no significance in maximum quantum yield (Fig. 1C). Lee et al. (2015) reported that there was a difference in seedling growth from the control plot depending on fertilization level of Thalictrum uchiyamae Nakai and Thalictrum rochebrunianum var. grandisepalum (H. Lev.) Nakai, but there was not much difference in growth by concentration. The results of this study also revealed that growth was better in fertilizer application than the control, but there was not much difference in growth depending on concentration. Shim and Kwon (2010) conducted a nutrient solution experiment on foliage plants

Table 3. Effect of substrate type on seedling growth characteristics of Veronica pyrethrina at 6 weeks after treatment

\begin{tabular}{|c|c|c|c|c|c|c|c|c|c|c|c|c|c|c|c|c|c|c|}
\hline \multicolumn{2}{|c|}{ Substrate } & \multicolumn{4}{|c|}{ Plant } & \multicolumn{3}{|c|}{ Leaves } & \multirow{2}{*}{$\begin{array}{l}\text { No. of } \\
\text { leaves }\end{array}$} & \multirow{2}{*}{\multicolumn{2}{|c|}{$\begin{array}{l}\text { Longest } \\
\text { root length } \\
(\mathrm{cm})\end{array}$}} & \multicolumn{3}{|c|}{ Fresh weight (mg) } & \multicolumn{4}{|c|}{ Dry weight (mg) } \\
\hline Type & Ratio & height $(\mathrm{cm}$ & & width $(\mathrm{cm}$ & & $\begin{array}{c}\text { length } \\
(\mathrm{cm})\end{array}$ & & width (cm) & & & & Shoot & Root & & Shoot & & Root & \\
\hline $\mathrm{CS}$ & & $1.7 \pm 0.09$ & $a^{z}$ & $4.4 \pm 0.08$ & $\mathrm{a}$ & $1.7 \pm 0.03$ & $\mathrm{a}$ & $1.5 \pm 0.06 \quad \mathrm{a}$ & $8.1 \pm 0.18$ & $\mathrm{a}$ & $7.3 \pm 0.19 \quad b$ & $201.3 \pm 12.96$ & a $49.3 \pm 2.49$ & $\mathrm{~b}$ & $19.6 \pm 1.11$ & $\mathrm{a}$ & $3.5 \pm 0.13$ & $\mathrm{c}$ \\
\hline PT:PL ${ }^{y}$ & $1: 1$ & $1.4 \pm 0.08$ & c 3 & $3.4 \pm 0.06$ & $\mathrm{c}$ & $1.3 \pm 0.02$ & $\mathrm{c}$ & $1.1 \pm 0.01 \quad \mathrm{c}$ & $6.5 \pm 0.13$ & $\mathrm{c}$ & $9.9 \pm 0.19 \quad$ a & $85.3 \pm 1.72$ & c $64.2 \pm 5.28$ & $\mathrm{~b}$ & $12.6 \pm 0.42$ & $\mathrm{~b}$ & $5.7 \pm 0.08$ & b \\
\hline PT:PL & $3: 1$ & $1.5 \pm 0.10$ & bc & $4.0 \pm 0.04$ & $\mathrm{~b}$ & $1.6 \pm 0.01$ & $\mathrm{~b}$ & $1.3 \pm 0.01 \quad \mathrm{~b}$ & $7.8 \pm 0.11$ & $\mathrm{a}$ & $10.2 \pm 0.46 \quad \mathrm{a}$ & $134.5 \pm 3.42$ & b $84.5 \pm 8.81$ & $\mathrm{a}$ & $20.4 \pm 0.70$ & $\mathrm{a}$ & $6.0 \pm 0.30$ & $\mathrm{~b}$ \\
\hline PT:PL & $4: 1$ & $1.5 \pm 0.10$ & $\mathrm{~b} 3$ & $3.9 \pm 0.05$ & $\mathrm{~b}$ & $1.6 \pm 0.02$ & at & $1.3 \pm 0.02 \quad \mathrm{~b}$ & $7.3 \pm 0.08$ & $\mathrm{~b}$ & $10.0 \pm 0.15 \quad \mathrm{a}$ & $131.3 \pm 1.17$ & b $\quad 98.4 \pm 6.4$ & $\mathrm{a}$ & $18.2 \pm 0.31$ & $\mathrm{a}$ & $7.0 \pm 0.4$ & a \\
\hline Signific & & $* *$ & & $* * *$ & & $* * *$ & & $* * *$ & $* * *$ & & $* * *$ & $* * *$ & $* *$ & & $* * *$ & & $* * *$ & \\
\hline
\end{tabular}

${ }^{2}$ Mean separation within columns by Duncan's multiple range test at $p \leq .05$.

${ }^{\mathrm{y}} \mathrm{CS}$, commercial substrate; PT, peatmoss; PL, perlite.

${ }^{\mathrm{x}} \mathrm{Mean} \pm \mathrm{SD}$.

${ }^{* * * * * *}$ significant at $p \leq .01$ or .001 , respectively.

Table 4. Effect of fertilization levels on the growth characteristics of Veronica pyrethrina at 5 weeks after treatment

\begin{tabular}{|c|c|c|c|c|c|c|c|c|c|c|c|c|}
\hline \multirow{2}{*}{$\begin{array}{l}\text { Fertilizer } \\
\text { content } \\
\left(\mathrm{mg} \cdot \mathrm{L}^{-1}\right)\end{array}$} & \multicolumn{3}{|c|}{ Plant } & \multicolumn{3}{|c|}{ Leaves } & \multirow{2}{*}{$\begin{array}{l}\text { No. of } \\
\text { leaves }\end{array}$} & \multirow{2}{*}{$\begin{array}{l}\text { Longest } \\
\text { root length } \\
(\mathrm{cm})\end{array}$} & \multicolumn{2}{|c|}{ Fresh weight (mg) } & \multicolumn{2}{|c|}{ Dry weight (mg) } \\
\hline & height $(\mathrm{cm}$ & & width (cm) & length $(\mathrm{cm})$ & width $(\mathrm{cm})$ & & & & Shoot & Root & Shoot & Root \\
\hline 500 & $2.1 \pm 0.1$ & $\mathrm{a}$ & $6.4 \pm 0.07 \quad \mathrm{a}$ & $2.5 \pm 0.04 \quad \mathrm{a}$ & $2.2 \pm 0.06$ & $\mathrm{a}$ & $7.3 \pm 0.13$ & $6.6 \pm 0.06$ & $359.0 \pm 12.97$ & $110.3 \pm 8.63$ & $43.9 \pm 1.83$ & $8.4 \pm 0.22$ \\
\hline 1000 & $1.9 \pm 0.14$ & $\mathrm{a}$ & $6.1 \pm 0.19 \quad a b$ & $2.5 \pm 0.06 \quad \mathrm{a}$ & $2.2 \pm 0.04$ & $\mathrm{a}$ & $7.5 \pm 0.39$ & $6.4 \pm 0.55$ & $402.9 \pm 43.0$ & $113.3 \pm 20.09$ & $46.5 \pm 2.75$ & $9.1 \pm 0.29$ \\
\hline 2000 & $2.1 \pm 0.06$ & $\mathrm{a}$ & $6.3 \pm 0.15 \mathrm{a}$ & $2.6 \pm 0.07 \quad a$ & $2.3 \pm 0.10$ & $\mathrm{a}$ & $7.1 \pm 0.13$ & $7.8 \pm 0.53$ & $423.6 \pm 50.28$ & $96.3 \pm 17.54$ & $45.4 \pm 1.23$ & $8.3 \pm 0.40$ \\
\hline Significance & $*$ & & $*$ & * & $*$ & & NS & NS & NS & NS & NS & NS \\
\hline
\end{tabular}

${ }^{\mathrm{z}}$ Mean separation within columns by Duncan's multiple range test at $p \leq .05$.

${ }^{\mathrm{x}} \mathrm{Mean} \pm \mathrm{SD}$.

NS, ${ }^{*}$ Non-significant or significant at $p \leq .05$ 
like Spathiphyllum and Hedera helix and reported that nutrient requirements varied depending on plat type and that clear fertilization standards for foliage plants are insufficient. $V$. pyrethrina Nakai did not show high nutrient requirements, and thus it does not seem to require more than $500 \mathrm{mg} \cdot \mathrm{L}^{-1}$ concentration in fertilizer application, and to increase the yield and consider the economic aspect, concentration below $500 \mathrm{mg} \cdot \mathrm{L}^{-1}$ may seem effective. Moreover, it is important to determine the optimal level of fertilizer concentration for plant bodies for cultivation, propagation, and supply of native plants in the future.

In sum, when raising seedlings of $V$. pyrethrina Nakai, it is effective to use $10 \mathrm{~mL}$ cell plug trays and horticultural substrate by itself and apply $500 \mathrm{mg} \cdot \mathrm{L}^{-1}$ fertilizers to increase seedling growth and yield as well as an economic effect.

\section{Conclusion}

This study was conducted to develop an effective technique for raising seedlings of $V$. pyrethrina Nakai, which is a native plant species in the Korean Peninsula, in plug trays. We used different cell sizes for trays, medium types, and fertilization levels for the experiment. To investigate the cell size of plug trays, we used 43,21 , and $10 \mathrm{~mL}$ cell plug trays. We filled up the $10 \mathrm{~mL}$ cell tray with horticultural substrate and mixed substrate of peat moss and perlite in the ratio of $1: 1$, $3: 1$, and $4: 1$ to examine growth depending on substrates. To check the difference by fertilizer concentration, we set water-soluble fertilizers as $0,500,1000$, and $2000 \mathrm{mg} \cdot \mathrm{L}^{-1}$. Growth of $V$. pyrethrina Nakai depending on tray cell size did not show significance by type of plug trays, but root pruning was high in $10 \mathrm{~mL}$. By substrate type, plant length, plant width, leaf length, leaf width, and shoot fresh weight were highest in the horticultural substrate, followed by $4: 1$, $3: 1$, and $1: 1$. Growth by fertilization level was higher in all treatment plots that were fertilized compared to the control plot, and there was no significant difference between 500,1000 , and $2000 \mathrm{mg} \cdot \mathrm{L}^{-1}$. The results of this study proved that it is most suitable to use $10 \mathrm{~mL}$ cell plug trays when raising seedlings of $V$. pyrethrina Nakai, sow seeds with horticultural substrates, and apply fertilizers with less than $500 \mathrm{mg} \cdot \mathrm{L}^{-1}$ concentration.

\section{References}

Albach, D.C., S.R. Jensen, F. Özgökce, and R.J. Grayer. 2005. Veronica: chemical characters for the support of phylogenetic relationships based on nuclear ribosomal and plastid DNA sequence data. Biochem. Syst. Ecol. 33(11):1087-1106. https://doi.org/10.1016/j.bse.2005.06.002

Choi, J.M., S.K. Jeong, K.H. Cha, H.J. Chung, and K.S. Seo. 2000. Deficiency symptom, growth characteristics, and nutrient uptake of 'Nyoho' strawberry as affected by controlled nitrogen concentrations in fertilizer solution. J. Korean Soc. Hortic. Sci. 41(4):339-344.

Compton, J.E., L.S. Watrud, L.A. Porteous, and S. DeGrood. 2004. Response of soil microbial biomass and community composition to chronic nitrogen additions at Harvard forest. For. Ecol. Manag. 196(1):143-158. https://doi.org/10.10 16/j.foreco.2004.03.017

Frey, S.D., M. Knorr, J.L. Parrent, and R.T. Simpson. 2004. Chronic nitrogen enrichment affects the structure and function of the soil microbial community in temperate hardwood and pine forests. For. Ecol. Manag. 196(1): 159-171. https://doi.org/10.1016/j.foreco.2004.03.018

Hernández, E.I., A. Vilagrosa, V. Luis, M. Llorca, E. Chirino, and V. Vallejo. 2009. Root hydraulic conductance, gas exchange and leaf water potential in seedlings of Pistacia lentiscus L. and Quercus suber L. grown under different fertilization and light regimes. Environ. Exp. Bot. 67(1): 269-276. https://doi.org/10.1016/j.envexpbot.2009.07.004

Hwang, K.S., S.T. Joo, S.S. Ha, K.D. Kim, and Y.K. Joo. 2018. Seedling plug and cutting method for multipropagation of ornamental Miscanthus spp. Weed Turfgrass Sci. 7:275-282. https://doi.org/10.5660/WTS.2018.7.3.275

ICL Specialty Fertilizers. 2021. Retrieved July 28, 2021 from https://icl-sf.com/global-en/products/ornamental_h orticulture/2113-peters-professional-allrounder/

Ito, T. 1992. Present state of transplant production practices in Japanese horticultural industry. In Transplant production systems. Springer. pp. 65-82. https://doi.org/10.1007/97 8-94-011-2785-1_4

Juntunen, M.L., T. Hammar, and R. Rikala. 2003. Nitrogen and phosphorus leaching and uptake by container birch seedlings (Betula pendula Roth) grown in three different fertilizations. New Forests. 25:133-147. https://doi.org/1 0.1023/A:1022686402578 
Kim, C.K., J.Y. Oh, and S.J. Kang. 2001. Effect of plug cell size and seedling age on growth and yield of Chinese chives (Allium tuberosum R.).

Kim, S.E., M.H. Lee, B.J. Ahn, and Y.S. Kim. 2013. Effects of spacing and plug cell size on seedling quality and yield and qualities of tomatoes. Prot. Hortic. Plant Fact. 2(3):256-261.

Kim, Y.S., Y.G. Park, and B.R. Jeong. 2019. Seedling quality, and early growth and fruit productivity after transplanting of squash as affected by plug cell size and seedling raising period. Prot. Hortic. Plant Fact. 28(3):185-196. https://doi.org/10.12791/KSBEC.2019.28.3.185

Ku, H-H., S.G. Lee, M.H. Chiang, J.L. Choi, and S.E. Lee. 2019. Effects of $\mathrm{pH}$ of soil medium on the growth and nutrient absorption of cultivated and native Chinese chives plants. Korean J. Environ. Biol. 37(1):42-47. https://doi. org/10.11626/KJEB.2019.37.1.042

Korea Plant Names Index (KPNI). 2021a. Retrieved July 28, 2021 from http://www.nature.go.kr/kpni/stndasrch/dt 1/selectNtnStndaPlantList2.do?mn=KFS_29_06_01\&am $\mathrm{p}$;orgId=kpni

Korea Plant Names Index (KPNI). 2021b. Retrieved July 28, 2021 from http://www.nature.go.kr/kpni/stndasrch/dt 1/selectNtnStndaPlantList2.do

Korea Plant Names Index (KPNI). 2021c. Retrieved July 28, 2021 from http://www.nature.go.kr/kbi/plant/pilbk/s electPlantPilbkDtl.do

Kwon, Y.H., H.H. Kwon, M. Gil, M.J. Jeong, S.Y. Kim, and Y.H. Rhie. 2020. Growth of Veronica nakaiana and Veronica pyrethrina under different shading levels. Flower Res. J. 28(4):331-339. https://doi.org/10.11623/frj.2020. 28.4.12

Lee, S.P., S.K. Kim, S.H. Chung, B.S. Choi, and S.C. Lee. 1998. Effects of soil $\mathrm{pH}$ on crude components and essential oil contents of codonopsis lanceolata trautv. Korean J. Med. Crop Sci. 6(4):239-244.

Lee, S.C., J.S. Lee, and S.J. Jeong. 2005. Germination and seedling growth of Miscanthus sacchariflorus as influenced by different plug cells and medium composition. J. Korean Soc. Hortic. Sci. 23(3)315-318.

Lee, S.I., S.H. Yeon, J.S. Cho, M.J. Jeong, and C.H. Lee. 2020a. Optimization of cultivation conditions on effective seedlings of Veronica rotunda var. subintegra (Nakai) T. Yamaz. Prot. Hortic. Plant Fact. 29(2):181-188. https:
//doi.org/10.12791/KSBEC.2020.29.2.181

Lee, S.I., S.H. Yeon, J.S. Cho, M.J. Jeong, and C.H. Lee. 2020b. Growth characteristics of Veronica rotunda var. subintegra (Nakai) T. Yamaz. according to several cultivation conditions. J. Korean Plant Resour. 33(1):24-32. https://doi.org/10.7732/kjpr.2020.33.1.24

Lee, W.H., S.Y. Lee, J.H. Kang, T.J. Lee, and K.S. Kim. 2015. Effect of fertilizer levels and shading rate on seeding growth of Thalictrum species native to korea. J. Korea Soc. Environ. Restor. Technol. 18(1):83-89. https://doi.o rg/10.13087/kosert.2015.18.1.83

Nam, H.H., J.H. Woo, and K.B. Choi. 2003. Growth response of seedlings of annual bedding plants influenced by raising period and cell size of plug tray. J. Korean Soc. Hortic. Sci. 44(2):223-227

Nelson, P.V. 1991. Greenhouse operation and management. Englewood Cliffs, State of New Jersey: Prentice Hall.

Rural Development Administration (RDA). 2021. Retrieved July 28, 2021 from https://www.nongsaro.go.kr/portal/s earch/nongsaroSearch.ps?menuId=PS00007\&categoryN ame $=\mathrm{SCH} 10 \&$ sortOrdr $=01 \&$ pageIndex $=1 \&$ pageSize $=1$ $0 \&$ pageUnit $=10 \&$ includeWord $=\&$ exEqWord $=\& \mathrm{ikEqW}$ ork $=\&$ excludeWord $=\&$ Hflag $=\&$ qura $=\&$ reCountingYn $=$ $\mathrm{N} \&$ field $=\mathrm{SCH} 01 \&$ searchWord $=\% \mathrm{EA} \% \mathrm{~B} 3 \% \mathrm{~B} 5 \% \mathrm{EC} \%$ A $0 \% 95 \% \mathrm{EC} \% 9 \mathrm{C} \% \mathrm{~A} 1 \% \mathrm{~EB} \% \mathrm{AC} \% 98$

Ryu, B.Y. 2004. Selection of native plants for the use of veranda container garden at apartment house. J. Korean Soc. People Plants Environ. 7(2):19-23.

Shim, M.S. and O.K. Kwon. 2010. Growth responses of various ornamental foliage plants to nutrient solution strength. Prot. Hortic. Plant Fact. 19(4):210-216.

Shin, Y.A., K.Y. Kim, Y.C. Kim, T.C. Seo, J.H. Chung, and H.Y. Pak. 2000. Effect of plug cell size and seedling age on seedling quality and early growth after transplanting of red pepper. J. Korean Soc. Hortic. Sci. 41(1):49-52.

Song, S.J., M.J. Jeong, S.Y. Kim, and S.Y. Lee. 2020. Phenotypic plasticity and ornamental quality of four Korean native Veronica Taxa following different light intensity treatment. Flower Res. J. 28(3):123-131.

Song, S.J., U.S. Shin, H.J. Oh, S.Y. Kim, and S.Y. Lee. 2019. Seed germination responses and interspecific variations to different incubation temperatures in eight Veronica species native to Korea. Hortic. Environ. Biotechnol. 37(1):20-31 
Song, Y.j., W.K. Choi, and H.Y. Jin. 2015. The current condition and improvement plan of native herbaceous plants in selling online. J. Korean Soc. People Plants Environ. 18(4):289-297. https://doi.org/10.11628/ksppe. 2015.18.4.289

Thirukkumaran, C.M. and D. Parkinson. 2002. Microbial activity, nutrient dynamics and litter decomposition in a Canadian rocky mountain pine forest as affected by
$\mathrm{N}$ and P fertilizers. For. Ecol. Manag. 159(3):187-201. https://doi.org/10.1016/S0378-1127(01)00432-7

Yoo, Y.K. and Y.S. Roh. 2012. Effects of cutting condition on growth of rooted cuttings and cut flower in plug cutting of Dendranthema grandiflorum 'Baekma'. Korean J. Hortic. Sci. Technol. 30(1):13-20. https://doi.org/10.7235/hort.2 012.11071 